\title{
Magdalena Rzemieniak
}

Politechnika Lubelska

e-mail:m.rzemieniak@pollub.pl

\section{PARADOKSY W SYTUACJACH KRYZYSOWYCH I TOŻSAMOŚCI ORGANIZACJI}

\section{PARADOXES IN CRISIS AND CORPORATE IDENTITY}

DOI: $10.15611 /$ noz.2016.1.10

Streszczenie: Celem artykułu jest analiza problematyki paradoksów w sytuacjach kryzysowych z perspektywy komunikacyjnej oraz w kontekście tożsamości organizacji. Badania wskazują, że dynamika tożsamości organizacji jest podobna do dynamiki sytuacji kryzysowych. $Z$ badań empirycznych nad tożsamością organizacji wynika, że taktyki kategoryzacyjne tylko na poziomie struktury tożsamości deprecjonują niektóre atrybuty organizacji. Działania będące reakcją na kryzysowe zagrożenie tożsamości organizacji wskazują, że niezbędna jest selektywna kategoryzacja, podkreślająca ważne atrybuty tożsamości organizacji. W pracy zastosowano badania oparte na źródłach wtórnych oraz metodę obserwacji uczestniczącej eksperta i praktyka od lat zajmującego się problematyką tożsamości organizacji i public relations.

Słowa kluczowe: kryzys, tożsamość, public relations.

Summary: The purpose of this article is to analyse the issue of paradox in crisis situations from the standpoint of communication and in the context of the corporate identity. The research shows that the dynamics of corporate identity is similar to the dynamics of the crisis situations. The empirical studies on corporate identity reveal that the categorisation strategies that operate exclusively at the level of identity structure and which regard the reaction to the threat to the corporate identity, used by the company members, indicate that the selective categorisation prioritises the attributes that are different from those prone to threats: e.g. when certain corporate identity attributes are depreciated. The research used in this work was carried out on secondary sources . Moreover, the author of this article has used the method of participant observation of expert, i.e. herself, who has spent years on dealing with the issues of corporate identity and public relations.

Keywords: crisis, corporate identity, public relations. 
Magdalena Rzemieniak

Dwadzieścia lat trwa budowanie wizerunku, a pięć minut jego zrujnowanie. Gdy o tym pomyślisz, będziesz postepowat inaczej.

W. Buffet

\section{Wstęp}

Paradoks oznacza sprzeczne elementy, które wydają się logiczne w izolacji, ale absurdalne i irracjonalne, jeśli pojawiają się razem. Wiele badań prowadzonych przez różnych badaczy reprezentujących różne zainteresowania wykazuje, że takie sprzeczności mogą być osadzone także w działaniach o charakterze komunikacyjnym, promocyjnym oraz tożsamościowym.

Celem artykułu jest analiza problematyki paradoksów w sytuacjach kryzysowych z perspektywy komunikacyjnej oraz w kontekście tożsamości organizacji. Badania wskazują, że dynamika tożsamości organizacji jest podobna do dynamiki sytuacji kryzysowych. Z badań empirycznych nad tożsamością organizacji wynika, że taktyki kategoryzacyjne tylko na poziomie struktury tożsamości deprecjonują niektóre atrybuty organizacji. Działania będące reakcją na kryzysowe zagrożenie tożsamości organizacji wskazują, że niezbędna jest selektywna kategoryzacja, podkreślająca ważne atrybuty tożsamości organizacji.

\section{Istota kryzysu i tożsamości we współczesnej organizacji}

Termin „kryzys” pochodzi od greckiego słowa krisis (rozróżnienie, decyzja). Kryzys zarówno w grece, jak i w łacinie oznacza sytuację decydującą, punkt zwrotny jakiegoś niebezpiecznego rozwoju [Wojcik 2001, s. 567; Tomczonek 2010, s. 83]. Według niektórych naukowców koncepcja kryzysu wywodzi się z medycyny. Kryzysem nazywa się w niej stan organizmu, z którego mogą wynikać alternatywne rozwiązania: albo chory wyzdrowieje, albo umrze, albo nastąpi następny kryzys. Każdemu kryzysowi towarzyszy niepewność co do konsekwencji oraz odczuwanie stanu zawieszenia. Podczas kryzysu wydarzenia następują szybko i gwałtownie, a ich skutki zazwyczaj są nieodwracalne [Murdoch 2003, s. 10].

Kryzys jest stałym elementem współczesnego świata, a co za tym idzie - także i funkcjonowania organizacji. Czynnikami sprzyjającymi występowaniu kryzysów są dynamicznie zmieniające się otoczenie oraz pojawianie się trudnych do przewidzenia lub nieprzewidzianych zdarzeń. Współcześnie nasila się występowanie sytuacji kryzysowych. Można powiedzieć, że kryzys to każdy czynnik zakłócający prawidłowe funkcjonowanie organizacji. Są branże, w których kryzys jest zjawiskiem bardzo częstym, a groźba jego wystąpienia jest praktycznie ciągła - jak na przykład branża transportowa. 
Istnieje wiele różnych określeń kryzysu. Można go zdefiniować nawet jako zapalną sytuację, która nadweręża dobre imię (reputację) organizacji, naraża jej przedstawicieli na krytykę albo ośmieszenie, wywołuje zakłopotanie. Kryzys to sytuacja, kiedy kierownictwo organizacji albo jej produkty znajdują się w centrum nieprzychylnego zainteresowania mediów. Przez kryzys w organizacji rozumie się wydarzenie godzące w jej publiczny wizerunek. To także wyjątkowa sytuacja, trudna albo wręcz niemożliwa do przewidzenia, która wymaga umiejętności szybkiego reagowania oraz dużego doświadczenia w zarządzaniu, lecz zdaniem specjalistów może on być wykorzystany do poprawy wizerunku [Bulak 2001, s. 17]. Sytuacjami kryzysowymi mogą być wydarzenia spowodowane zarówno przez organizację (zachodzące w jej wnętrzu lub rozgrywające się poza nią), jak też zupełnie od niej niezależne [Black 2001, s. 78].

Zwiększenie zainteresowania tożsamością organizacji nastąpiło na fali rozwoju nurtu badań społecznych w zakresie nauk o zarządzaniu [Altkorn 2004]. Do tej pory problem zarządzania tożsamością pojawiał się w literaturze przedmiotu głównie w kontekście fuzji i przejęć, diametralnych zmian w otoczeniu czy też załamania wizerunku na skutek sytuacji kryzysowych [Christensen, Soren 2001, s. 292-315]. Momentem utrwalenia definicji tożsamości organizacji jest przyjęcie jej przez British Standard Institute [BSI 7000 Part 10, za: Berniak-Woźny 2011, s. 4]. Interdyscyplinarny charakter pojęcia tożsamości jest przyczyną wielu pomyłek czy bliskoznacznych zastosowań tego terminu. Zdarza się, że tożsamość bywa używana zamiennie z pojęciem „wizerunek” czy „reputacja”.

Według G. Davisa tożsamość organizacji to jej wewnętrzny obraz, dotyczący wyłącznie jej wewnętrznych interesariuszy - pracowników. Natomiast obraz postrzegany przez interesariuszy zewnętrznych G. Davis nazwał reputacją [Davies i in. 2001, s. 113]. Podstawy definicyjne tożsamości organizacji sformułowali S. Albert i D.A. Whetton pod koniec lat osiemdziesiątych XX w. [Albert, Whetton 1985, w: Berniak-Woźny 2011, s. 4] $]^{1}$, zaś C.J. Formbrun rozwinął dotychczasowe podejście do zbioru wartości i zasad, które pracownicy wiążą z przedsiębiorstwem, i wyróżnił składające się na tożsamość następujące elementy [Fombrun, Van Riel 1997, s. 5-13]:

- cechy postrzegane przez pracowników jako rdzenne,

- cechy odróżniające od innych organizacji,

- trwałe cechy łączące teraźniejszość i przeszłość z przyszłością.

Kolejni autorzy (D.A. Gioia, M. Schulz, K.G. Corley) rozszerzają koncepcję tożsamości organizacji o wszystkich interesariuszy i definiują ją jako „wszystko to, co rdzenne, charakterystyczne i trwałe dla organizacji" [Gioia, Schulz, Corley 2000, s. 63-82]. N. Markwick i C. Fill dokonują podziału interesariuszy na wewnętrznych i zewnętrznych, eksponując przy tym sposób budowania tożsamości [Marwick, Fill 1993, s. 10-16]. Według E.R. Graya i J.M.T. Balmera tożsamość organizacji oznacza

${ }^{1}$ Podstawy te potem zostały rozwinięte przez C.J. Fombrun [Fombrun 1996]. 
jej wyjątkowość i rzeczywistość i jest zintegrowana z wizerunkiem, reputacją i komunikacją organizacji. Komunikacja zaś jest procesem umożliwiającym postrzeganie tożsamości organizacji przez interesariuszy [Gray, Balmer 1998, s. 695-702]. Według nich wizerunek jest tym, „, co przychodzi na myśl, gdy usłyszymy nazwę lub gdy widzimy logo" [Gray, Balmer 1998, s. 695-702]. Jest to także wewnętrzny stan umysłu, wynikający z działań komunikacyjnych, by się zaprezentować interesariuszom przedsiębiorstwa" [Bromley 1993]. Mimo że wizerunek można, a nawet należy planować, kształtować, jest on podatny na wpływy mikro- i makrootoczenia, co może być przyczyną różnorakich opinii (od pozytywnych do negatywnych).

\section{Paradoks legitymizacji społecznej}

Zdarzają się przypadki, że zinterpretowana zewnętrzna tożsamość organizacji zachwieje wiarę członków danego przedsiębiorstwa w jego społecznie odpowiedzialne działanie. Dzieje się tak często w sytuacji kryzysowej, w czasie nasilonej krytyki przedsiębiorstwa. Powstaje tutaj problem tzw. legitymizacji organizacji. Organizacja osiąga legitymizację, jeśli jej interesariusze oraz wewnętrzna i zewnętrzna publiczność, będąca pod wpływem danej organizacji, zaaprobuje i poprzez cele oraz działania organizacji buduje jej reputację i pozwala jej przetrwać [Elsbach 1997, s. 57-88]. By zlikwidować negatywne postrzeganie legitymizacji danego przedsiębiorstwa, co pozwoli na odbudowywanie pozytywnie zinterpretowanej zewnętrznej tożsamości, w przedsiębiorstwach podejmowane są odpowiednie, już opisane działania antykryzysowe. Badania pokazują, że pewne taktyki interakcyjne są tutaj bardziej efektywne od innych. Na przykład w badaniach nad przemysłem mięsnym i hodowlanym w Kalifornii zaobserwowano zastosowanie pewnych taktyk broniących legitymizacji działań danego przemysłu. Opinia publiczna zarzucała hodowcom nielegalne wypasy publicznych terenów, a producentom mięsa - niszczenie środowiska, produkcję niezdrowej żywności przez używanie hormonów i antybiotyków, okrucieństwo wobec hodowanych zwierząt itp. Krytykowane przedsiębiorstwa broniły się, używając pewnych taktyk objaśniających, z których najbardziej efektywne okazały się [Konecki 2002, s. 74-78]:

- Przyznanie, iż pewne fakty miały miejsce (jest to bardziej efektywny środek perswazyjny niż zaprzeczenie).

- Jeśli pewne wydarzenia naruszały normy instytucjonalne, to objaśnianie ich w kategoriach instytucjonalnych, dotyczących stosowania procedur i odnoszenia się do struktur instytucjonalnych (na przykład przestrzeganie norm stanowych, współpraca ośrodków badawczych i przywoływanych przedsiębiorstw, przykładowo z Uniwersytetem Kalifornijskim) było bardziej efektywne, niż objaśnianie w kategoriach technicznych (dotyczących na przykład kategorii wydajnościowych i ekonomicznych). Jeśli wystąpiło postrzeżenie naruszenia instytucjonalnych norm, to przyznanie się do wystąpienia tych faktów łącznie z odniesieniem się do instytucjonalnych struktur, procedur czy celów jest bardziej 
efektywne w ochronie organizacyjnej legitymizacji niż objaśnienia, które zawierają tylko jeden z tych elementów.

Legitymizacja organizacji, paradoksalnie, może być także osiągnięta przez nielegalne działania, które spowodowały zwrócenie uwagi opinii publicznej na ważne społecznie problemy, których rozwiązanie stało się możliwe dopiero po zorganizowaniu paralegalnych lub nielegalnych akcji protestacyjnych i postrzeżeniu ich przez mass media oraz przez innych ważnych aktorów społecznych [Elsbach, Kramer, s. 442-476]. Jak wskazują wyniki badań, w ten sposób przedsiębiorstwa będące inicjatorami nielegalnych akcji (na przykład niektóre radykalne ruchy społeczne czy organizacje ekologiczne) uzyskiwały społeczną aprobatę i poparcie. Bardzo ważne w efektywnej kreacji odpowiedniego wizerunku przedsiębiorstwa było używanie określonych taktyk interakcyjnych przez jego przedstawicieli. Po zajściu nielegalnego zdarzenia (na przykład nielegalnego protestu blokującego przejazd głównymi ulicami miasta), koncentrującego uwagę opinii publicznej na danym przedsiębiorstwie, podejmuje ono następujące działania, które przebiegają według następującej sekwencji:

- Na początku prezentowane jest mediom instytucjonalne zaplecze przedsiębiorstwa, co ma swoją określoną moc perswazyjną. Przedsiębiorstwo kontaktuje się z mediami, ukazując im tzw. konformizm instytucjonalny. Pokazuje, iż jego struktura i procedury są izomorficzne z tymi, które posiadają inne legalne przedsiębiorstwa.

- Ponadto ukazuje legalne struktury, w tym rolę rzecznika prasowego, jako niezależne od ról uczestników działań nielegalnych (adecoupling).

- Następnie rzecznik prasowy angażuje się w wytwarzanie odpowiednich wrażeń u zewnętrznych obserwatorów przedsiębiorstwa (impression management).

- Ukazywana jest „niewinność” przedsiębiorstwa oraz przekazywane są pewne usprawiedliwienia, by zredukować negatywne wrażenia powstałe po zajściu nielegalnego zdarzenia.

- W kolejnym kroku używana jest retoryka podwyższająca wartość przedsiębiorstwa i samego zdarzenia oraz prezentuje się pogląd, iż przedsiębiorstwo miało pełne prawo do podjęcia odpowiednich działań.

W konsekwencji tych działań przedsiębiorstwo może osiągnąć legitymizację, tj. aprobatę i poparcie ważnych aktorów społecznych [Gioia, Thomas 2002, s. 370-403] (w: [Konecki, Tobera 2002, s. 74-78]).

Według K. Koneckiego powyższe działania legitymizujące przedsiębiorstwo i budujące jego wizerunek oraz zaprezentowana sekwencja tych działań jest efektywna również w działaniach innego typu organizacji, również organizacji trzeciego sektora, a więc ma pewien walor uniwersalny.

Wszystkie opisane próby odzyskiwania i budowania legitymizacji organizacji wiążą się z budową wizerunku przedsiębiorstwa. Jeśli tak jest, to zinterpretowana zewnętrzna tożsamość organizacji zależy od tego wizerunku, którego częścią jest również dynamika zmian związana z legitymizacją i delegitymizacją organizacji lub 
jej określonych działań. Należy zatem podkreślić ścisły związek wizerunku organizacji ze zinterpretowaną zewnętrzną tożsamością organizacji [Elsbach, Kramer, s. 442-476].

\section{Paradoksy w budowaniu tożsamości}

Jednym z kluczowych paradoksów w budowaniu tożsamości organizacji jest założenie, że każdy potrafi się komunikować. Działania tożsamościowe organizacji powinny być oparte na założeniach:

- Rzetelnej sztuki komunikowania się.

- Zaplanowanej, przemyślanej, długofalowej strategii komunikacji z otoczeniem.

- Budowaniu zaufania i zrozumienia między organizacją a jej odbiorcami oraz jej wiarygodności w oczach odbiorców.

- Umiejętności budowania trwałych relacji.

- Spójności wszystkich elementów komunikacji w organizacji.

Kolejne sprzeczności dotyczą mitu, że w działaniach wykorzystywanych do budowania tożsamości organizacji stosowana jest propaganda i manipulacja, zaś prawdziwie skuteczne techniki oparte są na przekazywaniu rzetelnych, uczciwych i prawdziwych informacji, prowadzeniu dialogu $\mathrm{z}$ otoczeniem oraz wsłuchiwaniu się w potrzeby otoczenia, budowaniu zaufania, zrozumienia i wiarygodności zgodnie z obowiązującymi kodeksami etycznymi („Osoby zajmujące się budowaniem tożsamości są zobowiązane do przestrzegania zasady prawdomówności oraz nierozpowszechniania informacji, które zgodnie z jego wiedzą i doświadczeniem, są nieprawdziwe, nieścisłe lub mogą wprowadzić odbiorcę w błąd").

\section{Zakończenie}

W artykule dokonano krytycznej analizy zjawisk paradoksów w kryzysach z perspektywy komunikacyjnej. Przeanalizowano także paradoksy w tworzeniu tożsamości organizacyjnej. Materiał kończy omówienie związków paradoksów w sytuacjach kryzysowych z legitymizacją tożsamości organizacji. Rozważania dotyczące kryzysu są wynikiem studiów literaturowych wzbogaconych doświadczeniem własnym autorki, jako wieloletniego praktyka public relations.

\section{Literatura}

Albert S., Whetton D.A., 2011, Organisational Identity, [w:] Cumming L.L., 1985, [w:] Berniak-Woźny J., Tożsamość organizacji i modele zarządzania tożsamościq organizacji, Zarządzanie Zmiana$\mathrm{mi}, \mathrm{nr} 2$.

Altkorn J., 2004, Podstawy marketingu, Wydawnictwo Instytut Marketingu, Kraków.

Berniak-Woźny J., 2011, Tożsamość organizacji i modele zarządzania tożsamościa organizacji, Zarządzanie Zmianami, nr 2. 
Black S., 2001, Public Relations, Dom Wydawniczy ABC, Warszawa.

Bromley D.D., 1993, Reputation, Image and Impression a Management, John Willey\&Sons, Chichester. Bulak P., 2001, Kryzysowe public relations, Marketing i Rynek, nr 7.

Christensen L.T., Soren A., 2001, Corporate identity and corporate image revisited, a semiotic perspective, European Journal of Marketing, no. 35.

Davies G., Chun R., da Silva R.V., Roper S., 2001, The personification the metaphor as a measurement approach for corporate reputation, Corporate Reputation Review, no. 4(2).

Elsbach K., 1997, Managing organisational legitymacy in the California cattle industry: The effectiveness of verbal accounts, Administraive Science Quarterly, vol. 39, no. 722.

Elsbach K., Kramer R., 2009, Members responses to organizational identity threats: Encountering and countering bussines week ranking, Administrative Science Quarterly, vol. 41.

Fombrun Cj., Van Riel C., 1997, The reputation landscape, Corporate Reputation Review, vol. 1, $\mathrm{Nr} 1-2$.

Gioia D., Thomas J., 1996, Identity, Image and issue of interpretation: Sensemaking during strategic change in academia, Administrative Science Quarterly, vol. 41.

Gioia D.A., Schulz M., Corley K.G., 2000, Organisational identity, image, and adaptive instability, The Academy of Management Review, vol. 25, no. 1.

Gray E.R., Balmer J.M.T., 1998, Managing corporate image and corporate reputation, Long Range Planning, vol. 31 , no. 5.

Konecki K., 2002, Tożsamość organizacyjna, [w:] Konecki K., Tobera P., Szkice z socjologii zarządzania, Wydawnictwo Uniwersytetu Łódzkiego, Łódź.

Marwick N., Fill C., 1993, What image do you project, Management Review, vol. 82, November.

Murdoch A., 2003, Komunikowanie w kryzysie. Jak ratować wizerunek firmy, Poltext, Warszawa.

Tomczonek Z., 2010, Kryzysy gospodarcze i ich przyczyny, Marketing i Rynek, nr 12 (grudzień).

Wojcik K., 2001, Public relations od A do Z, Agencja Wydawnicza Placet, Warszawa. 